\title{
Model Hewan Coba pada Penelitian Diabetes
}

\section{Animal Model in Diabetes Research}

\author{
Fauzul Husna $^{1^{*}}$, Franciscus D. Suyatna ${ }^{2}$, Wawaimuli Arozal ${ }^{2}$, Erni H. Purwaningsih ${ }^{3}$ \\ ${ }^{1}$ Department of Pharmacology, Faculty of Medicine, Universitas Syiah Kuala, Aceh, Indonesia \\ ${ }^{2}$ Department of Pharmacology, Faculty of Medicine, Universitas Indonesia, Jakarta, Indonesia \\ ${ }^{3}$ Department of Pharmacy, Faculty of Medicine, Universitas Indonesia, Jakarta, Indonesia
}

\section{ARTICLE HISTORY \\ Received: February 2019 \\ Revised: July 2019 \\ Accepted: October 2019}

\begin{abstract}
ABSTRAK
Model hewan coba telah banyak memberi kontribusi terhadap penemuan ilmiah selama bertahun-tahun. Model hewan berfungsi sebagai pengganti dan belum tentu semua model identik dengan subjek yang dimodelkan. Oleh karena itu, pemilihan model hewan yang tepat untuk mempelajari dan memahami pengaruh lingkungan dan gen terhadap patogenesis suatu penyakit sangat penting. Model hewan yang ideal adalah hewan yang memiliki kesamaan dalam proses yang ditiru, mudah dipelihara, mampu memproduksi keturunan yang banyak, biaya perawatan murah, satu ekor dapat memberi sampel darah dan jaringan, komposisi genetiknya diketahui dan status penyakitnya diketahui dan dapat dijelaskan.
\end{abstract}

Penelitian mengenai diabetes mellitus (DM) dan resistensi insulin terus dilakukan untuk menemukan strategi pengobatan yang tepat dalam mencegah dan mengatasi diabetes dan komplikasinya. Penelitian untuk menemukan strategi pengobatan harus dimulai dari uji in vitro awal sampai uji klinik. Serangkaian penelitian in vivo menggunakan hewan coba, sehinga diperlukan model hewan yang sesuai dengan keadaan atau penyakit pada manusia untuk mendapatkan gambaran pola yang mirip dengan manusia. Pada artikel ini akan dibahas mengenai berbagai jenis model hewan coba yang biasa digunakan pada penelitian DM.

Kata kunci : model hewan; diabetes; streptozotocin

\begin{abstract}
The animal model has been widely used and contributed vastly to the scientific research over the years. While it can be used as an alternate subject in a study, the selection of the animal is crucial to assess and investigate the influence of the environment and genes on the pathogenesis of a disease. Many factors contribute to the choosing of the animal. They can be ranged from the similarities with the modelled object, easily looked after with less expensive cost, good reproductive performance, ability to produce blood and tissue samples, well-known genetic composition, and the status of the disease can be explained.
\end{abstract}

Research has been taking place to investigate and find the best approach to prevent and deal with diabetes mellitus (DM) and insulin resistance and its complications. It starts with an initial in vitro method and finished with a clinical trial. Similarly, a series of in vivo studies using the animal model has been done aiming at figuring out its conditions or diseases that are identical to that of humans. This article discusses a variety of animal models frequently used in DM research.

Keywords: animal model; diabetes; streptozotocin
${ }^{*}$ Corresponding author

Email:fauzul.husna@unsyiah.ac.id

\section{PENDAHULUAN}

Secara umum, model hewan coba diklasifikasikan menjadi dua yaitu model hewan yang diinduksi spontan atau genetik dan model hewan yang diinduksi secara eksperimental atau non genetik. Model hewan spontan atau genetik adalah hewan normal yang memiliki persamaan fenotip dengan manusia atau spesies hewan yang abnormal yang disebabkan oleh mutasi spontan. Model hewan induksi atau non genetik adalah hewan yang diubah status fisiologis normalnya melalui pembedahan, modifikasi genetik dan pemberian zat kimia (Dorothy, 2012). Model non genetik lebih sering digunakan dibandingkan model genetik karena biaya lebih murah, ketersediaannya lebih banyak, metode induksi dan pemeliharaan lebih mudah. Kekurangan 
model hewan spontan adalah perkembangannya sering tidak dapat diprediksi (Maurer \& Quimby, 2015).

Tikus merupakan hewan yang paling sering digunakan sebagai model hewan pada penelitian biomedik dan tingkah laku karena tikus memiliki sifat seperti masa gestasi singkat, masa hidup relatif singkat, jinak dan memiliki latar belakang kesehatan dan genetik yang sudah diketahui. Selain itu, ukuran tikus juga cukup besar untuk dilakukan pembedahan atau transplantasi organ. Genom tikus memiliki kedekatan homologi dengan genom manusia sehingga manipulasi pada genom tikus dapat menghasilkan model hewan yang fenotipnya mirip dengan penyakit pada manusia. Tikus Laboratorium yang lazim digunakan adalah Rattus norvegicus yang merupakan ordo Rodentia dan famili Muridae. Genus Rattus terdiri atas 56 spesies namun dua spesies yang digunakan untuk penelitian adalah Norway rat (Rattus norvegicus) dan Black rat (Rattus rattus). Saat ini Norway rat sudah secara umum digunakan (Otto et al., 2015).

Sejarah penggunaan tikus sebagai subjek penelitian, pertama kali tercatat pada tahun 1828 dan penelitian yang memelihara tikus terjadi pada akhir abad ke 18. Wistar Institute, Philadelphia adalah institusi penelitian independen tertua di US yang melakukan penelitian menggunakan hewan coba pada tahun 1894 (Lindsey \& Baker, 2006; Otto et al., 2015). Saat ini untuk mendapatkan ijin penggunaan obat baru pada penelitian hewan atau manusia harus sudah melakukan uji toksisitas pada spesies hewan yang kecil (seperti rodensia) dan satu pada kelompok hewan yang lebih besar (seperti anjing atau non primata). Tikus telah digunakan sebagai hewan standar pada uji toksikologi, teratologi dan karsinogenesis bahkan saat ini tikus juga sudah digunakan untuk penelitian tingkah laku, neurologi, nutrisi, genetik, imunologi, penyakit infeksi dan metabolik (Suckow et al., 2017).

Penggunaan tikus sebagai hewan coba perlu memperhatikan beberapa standar yang telah dikeluarkan oleh National Research Council tahun 2011 yaitu Guide for the Care and Use of Laboratory Animal (National Research Council, 2011). Standar yang harus diperhatikan meliputi manajemen rumah pemeliharaan tikus dan sifat biologi tikus. Standar manajemen rumah pemeliharaan tikus meliputi lingkungan makro seperti dinding, atap dan lantai pada rumah pemeliharaan tikus, suhu ruangan, penerangan dan kandang tikus. Standar lainnya yang harus diperhatikan adalah sifat biologi tikus. Penelitian sebaiknya telah mengetahui gambaran umum, organ sensorik, nilai parameter fisiologis normal, nutrisi dan tingkah laku tikus (Otto et al., 2015). Tikus putih (tikus Norway) memiliki telinga yang kecil dan tebal, ekornya $85 \%$ dari panjang tubuhnya. Pertumbuhan bulu pada tikus muda bersiklus dan pada tikus dewasa terjadi setiap 17 hari. Tikus betina biasanya memiliki 12 puting susu. Berat badan dan laju pertumbuhan tergantung strain dan sumber tikus. Sprague-Dawley lebih besar dari Wistar dan Fisher344 adalah tikus terkecil dibanding strain tikus lainnya (Otto et al., 2015). Parameter nilai fisiologis normal pada tikus dapat dilihat dari Tabel 1. Nilai ini hanya akurat pada tikus yang berasal dari sumber dan strain yang sama. Faktorfaktor seperti usia, status patogen, metode pengumpulan sampel dan kondisi kandang merupakan variabel penting pada nilai normal ini (Pérez et al., 1997). Tikus adalah omnivora dan diet yang adekuat telah tersedia secara komersil. Aklimatisasi dan penyapihan sangat mempengaruhi tingkah laku dan stres pada tikus (Shalev et al., 1998). Tikus lebih aktif pada malam hari tapi tetap makan dan bergerak sepanjang hari. Lebih aktif pada pagi hari dibanding sore hari. Ritme sirkadian juga perlu dipertimbangkan dalam pemeriksaan tingkah laku (Saibaba et al., 1996). Frekuensi gentle handling akan mempengaruhi kejinakan tikus. Semakin sering tikus dipegang maka tikus akan semakin jinak sehingga mengurangi kecelakaan dan stres pada tikus. Handling yang kasar dan jarang akan mencetus ketakutan dari tikus dan menyebabkan stres pada tikus (Hirsjarvi et al., 1990).

\section{Model Hewan Coba Diabetes}

Model hewan untuk penelitian diabetes idealnya mempunyai fenotip yang dapat menggambarkan semua patogenesis DM yang sama dengan yang terjadi pada manusia, namun saat ini belum ada satu model tunggal yang dapat menjelaskan patofisiologi DM secara lengkap seperti yang terjadi pada manusia. Model non genetik menunjukkan kemiripan patogenesis dengan keadaan pada manusia. Model hewan diabetes non genetik adalah hewan yang dalam keadaan normal tidak mengalami DM dan perlakuan tertentu pada hewan tersebut menyebabkan hewan mengalami DM. Induksi DM dilakukan dengan cara membuang sebagian pankreas (pankreatektomi), manipulasi genetik, memberi zat kimia tertentu atau memanipulasi diet atau penggabungannya (Rees \& Alcolado, 2005). Berbagai modifikasi pada model hewan telah dilakukan untuk mendapatkan gambaran klinis dan patogenesis DM yaitu defisiensi insulin (disfungsi sel $\beta$-pankreas) dan resistensi insulin (Dorothy, 2012; Kaplan \& Wagner, 2006). Beberapa model tersebut dibahas berikut ini.

\section{A. Model hewan coba spontan atau genetik}

Salah satu cara untuk membuat model hewan DM adalah dengan meminimalisir efek leptin dengan cara menurunkan reseptor leptin atau produksi leptin. Leptin berperan dalam pengaturan berbagai efek yang menyebabkan sindrom metabolik. Reseptor leptin 
Tabel 1. Data fisiologis normal tikus (Otto et al., 2015)

\begin{tabular}{|c|c|}
\hline Tikus Dewasa & \\
\hline \multicolumn{2}{|l|}{ Berat } \\
\hline Jantan & $300-500 \mathrm{~g}$ \\
\hline Betina & $250-300 \mathrm{~g}$ \\
\hline Masa Hidup & $2,5-3$ tahun \\
\hline Suhu Tubuh & $37,5^{\circ} \mathrm{C}$ \\
\hline Tingkat Metabolisme Dasar (400g tikus) & $35 \mathrm{kcal} / 24 \mathrm{jam}$ \\
\hline Jumlah Kromosom (diploid) & 42 \\
\hline Masa Pubertas & $50 \pm 10$ hari \\
\hline Kehamilan & $21-23$ hari \\
\hline Jumlah Anak & $8-14$ \\
\hline Berat Lahir & $5-6 \mathrm{~g}$ \\
\hline Penyapihan & 21 hari \\
\hline Konsumsi Makanan /24 jam & $5 \mathrm{~g} / 100 \mathrm{~g} \mathrm{BB}$ \\
\hline Konsumsi Air /24 jam & $8-11 \mathrm{ml} / 100 \mathrm{~g} \mathrm{BB}$ \\
\hline \multicolumn{2}{|l|}{ Kardiovaskular } \\
\hline \multicolumn{2}{|l|}{ Tekanan darah } \\
\hline Sistolik & $116 \mathrm{mmHg}$ \\
\hline Diastolik & $90 \mathrm{mmHg}$ \\
\hline Denyut Jantung & 300-500 kali /menit \\
\hline Curah Jantung & $50 \mathrm{ml} / \mathrm{menit}$ \\
\hline Volume Darah & $6 \mathrm{ml} / 100 \mathrm{~g} \mathrm{BB}$ \\
\hline \multicolumn{2}{|l|}{ Pernafasan } \\
\hline Pernafasan/menit & 85 kali \\
\hline Volume Tidal & $1,5 \mathrm{~mL}$ \\
\hline Luas Permukaan Alveolar (400 g tikus) & $7,5 \mathrm{~m}^{2}$ \\
\hline \multicolumn{2}{|l|}{ Ginjal } \\
\hline Volume Urin /24 jam & $5.5 \mathrm{ml} / 100 \mathrm{~g} \mathrm{BB}$ \\
\hline Ekskresi $\mathrm{Na}^{+} / 24 \mathrm{jam}$ & $1,63 \mathrm{mEq} / 100 \mathrm{~g} \mathrm{BB}$ \\
\hline Eksresi $\mathrm{K}^{+} / 24$ jam & $0,83 \mathrm{mEq} / 100 \mathrm{~g} \mathrm{BB}$ \\
\hline Osmolaritas Urin & $1659 \mathrm{mOsm} / \mathrm{kgH}_{2} \mathrm{O}$ \\
\hline pH Urin & $7,3-8,5$ \\
\hline \multicolumn{2}{|l|}{ Analit serum } \\
\hline Glukosa & $115 \pm 16,9 \mathrm{mg} / \mathrm{dL}$ (jantan) \\
\hline Kreatinin & $0,70 \pm 0,11 \mathrm{mg} / \mathrm{dL}(\mathrm{jantan})$ \\
\hline
\end{tabular}


disebut fa. Mutasi buatan pada reseptor leptin (fa) menurunkan fungsi reseptor dan memberi gambaran hiperglikemia. Secara umum, pada manusia tidak terjadi defisit reseptor leptin, sehingga model hewan DM yang menunjukkan penurunan peran leptin kurang ideal sebagai model untuk menunjukkkan komplikasi pada manusia (Medical, 1991).

Contoh model hewan DM yang diinduksi secara spontan atau genetik adalah:

\section{Tikus Zucker}

Tikus Zucker atau Zucker fatty rat (ZFR) dikembangkan pertama kali pada tahun 1961 oleh Zucker. Nama lainnya adalah (fa/fa) fatty atau obese rat $\left(\right.$ Lepr $\left.^{\mathrm{fa}}\right)$. Model tikus ini sangat dikenal dan digunakan secara luas sebagai tikus yang obesitas secara genetik. Fenotipnya terjadi melalui mutasi resesif autosomal (fa) pada kromosom 5 sehingga menyebabkan disfungsi sinyal reseptor leptin di hipotalamus. Mutasi tersebut memperlihatkan fenotip obesitas pada usia 3-5 minggu dan pada usia 14 minggu komposisi tubuhnya mengandung 40\% lipid. Tikus Zucker obesitas tidak menunjukkan hiperglikemia tapi menunjukkan hiperlipidemia, hiperkolesterolemia, hiperinsulinemia serta hipertropi dan hiperplasia adiposit. Model tikus ini digunakan pada penelitian yang menghubungkan antara obesitas dengan DM non insulin dependent, penemuan obat antiobesitas dan insulin secretagogue (Srinivasan \& Ramarao, 2007).

Modifikasi tikus Zucker adalah tikus Zucker diabetic fatty (ZDF). Tikus ini dikembangkan khusus untuk hiperglikemia. Baik ZFR maupun ZDF digunakan dalam penelitian sindrom metabolik dan DM tipe 2 tapi Tikus ZDF dianggap sebagai model standar dan banyak digunakan sebagai model sindrom metabolik dan DM tipe 2. Tikus ZDF didapatkan dengan melakukan mutasi lanjutan pada tikus Zucker obesitas dan menunjukkan defisiensi reseptor leptin sehingga tikus ZDF berkembang menjadi obesitas dan hiperglikemia pada usia 8-10 minggu. Tikus jantan lebih rentan untuk mengalami DM pada model ini. Tikus ZDF juga memberi tanda lipotoksisitas dan down regulation pada transporter GLUT2 dan GLUT4, sehingga model ini dapat digunakan untuk meneliti mekanisme resistensi insulin dan disfungsi sel $\beta$ (Srinivasan \& Ramarao, 2007).

\section{Tikus spontaneously diabetic Torii (SDT)}

Tikus SDT adalah strain inbreed Spraque-Dawley yang digunakan untuk model DM tipe 2 non obesitas. Tikus SDT jantan mengalami peningkatan KGD pada usia 20 minggu disertai gangguan histopatologi pankreas. Sebelum mengalami diabetes, tikus SDT menunjukkan intoleransi glukosa disertai hipoinsulinemia. Tikus
SDT juga mengalami komplikasi retinopati, nefropati dan neuropati.(Sasase et al., 2013) Insiden terjadi DM pada tikus jantan adalah $100 \%$ pada usia 40 minggu, sedangkan pada tikus betina hanya 33\%. Beberapa peneliti mencoba memperpendek durasi onset DM dengan memodifikasi mutasi fa pada tikus ZFD ke tikus SDT sehingga memperoleh gambaran klinis obesitas, hiperglikemia dan hiperlipidemia lebih awal (Kemmochi et al., 2013).

\section{Tikus Goto-Kakizaki (GK)}

Tikus Goto-Kakizaki termasuk model hewan terbaik untuk DM tipe 2 non obesitas karena memberikan gambaran klinis yang biasa terjadi pada pasien DM. Tikus GK secara spontan menjadi DM melalui berbagai mekanisme yang memodifikasi gen, merusak metabolisme gestasional, sehingga memicu gangguan berbagai organ seperti pankreas dan jaringan yang menjadi target utama insulin pada keturunannya.

\section{B. Model hewan coba yang diinduksi atau non genetik}

Model hewan non genetik yang berkembang untuk penelitian diabetes saat ini adalah:

1. Model aloksan atau streptozotosin pada tikus dewasa

Streptozotosin (STZ) dan aloksan merupakan zat kimia yang sering digunakan untuk menginduksi hewan coba menjadi DM. Goldner dan Gomori adalah peneliti yang pertama kali menggunakan aloksan untuk menginduksi DM pada hewan pada tahun 1943 (Goldner \& Gomori, 1943). STZ atau 2-deoksi-2-(3-metil-nitrosourea)-1-Dglukopiranosa adalah senyawa yang alami terdapat pada bakteri Streptomyces achromogenes dan memiliki efek antibakteri spektrum luas. Berat molekul STZ adalah $265 \mathrm{~g} / \mathrm{mol}$ dan strukturnya terdiri atas gugus nitrosourea dengan gugus metil terikat pada ujung yang satu dan molekul glukosa terikat pada ujung lainya (Eleazu et al., 2013). Awalnya STZ digunakan sebagai obat kemoterapi untuk mengobati kanker pankreas yang bermetastasis dan keganasan lainnya (Lenzen, 2008). Pada tahun 1963, Rakieten dan temannya melaporkan bahwa STZ bersifat diabetogenik. Sejak saat itu, STZ digunakan sebagai salah satu obat untuk menginduksi DM pada hewan coba (Rakieten et al., 1963).

STZ dapat menginduksi DM pada tikus, mencit, monyet, hamster, kelinci dan guinea pig. STZ bersifat sitotoksik terhadap sel $\beta$ pankreas dan efeknya dapat terlihat 72 jam setelah pemberian STZ dan tergantung pada dosis pemberian. Efek toksik STZ diawali dengan ambilan STZ ke dalam sel melalui transporter glukosa-2 (GLUT2) afinitas rendah yang terdapat di membran plasma sel $\beta$, 
sel hepatosit dan sel tubulus ginjal. Hal ini dibuktikan dengan penelitian pada sel yang memproduksi insulin dan tidak mengekspresikan GLUT2 bersifat resisten terhadap induksi dengan STZ (Elsner et al., 2000).

Efek toksiknya bersifat lebih selektif terhadap sel $\beta$ pankreas karena berdasarkan struktur kimia STZ yang memiliki gugus glukosa sehingga mempermudah masuknya STZ ke sel $\beta$ karena sel $\beta$ pankreas lebih aktif mengambil glukosa dibanding sel lainnya. Sel lain yang mengekspresikan GLUT2 seperti hepatosit dan sel tubulus ginjal juga rentan terhadap induksi dengan STZ. Hal ini yang menjelaskan tentang efek nefrotoksik dan hepatotoksik STZ. STZ juga menyebabkan kerusakan jantung dan jaringan lemak dan meningkatkan stres oksidatif, inflamasi dan disfungsi endotel (Valentovic et al., 2006).

Kematian sel yang disebabkan oleh pemberian STZ adalah karena gugus metilnitrosourea STZ menyebabkan metilasi DNA, terutama pada posisi $\mathrm{O}^{6}$ guanin. Hal ini mencetuskan kerusakan DNA yang pada akhirnya menyebabkan nekrosis sel $\beta$ pankreas melalui deplesi simpanan energi seluler. Selain itu, adanya usaha untuk memperbaiki DNA yang rusak melalui aktivasi poli ADP ribosa polimerase (PARP) akan semakin mengurangi $\mathrm{NAD}^{+}$selular (Eleazu et al., 2013).

Kematian sel yang disebabkan oleh STZ melibatkan tiga jalur yaitu (Eleazu et al., 2013):

a. Metilasi DNA melalui pembentukan ion carbonium $\left(\mathrm{CH}_{3}^{+}\right)$sehingga menyebabkan aktivasi enzim nuklear poli ADP-ribosa sintetase yang berperan pada mekanisme perbaikan sel

b. Produksi nitrit oksida

c. Pembentukan radikal bebas seperti hidrogen peroksida

Pemberian STZ menyebabkan peningkatan malondialdehid secara signifikan menurunkan aktivitas enzim antioksidan seperti katalase, glutation peroksidase dan superoksida dismutase. Selain itu, sel $\beta$ pankreas tidak memiliki katalase dan glutation peroksidase sehingga semakin rentan terhadap radikal bebas (Vergani et al., 2004). Mekanisme sitotoksisitas STZ juga melibatkan jalur sinyal yang melibatkan NFкB (Hunt et al., 1990; Matsuoka et al., 1997).

Senyawa lain yang sering digunakan untuk induksi DM pada hewan coba adalah aloksan. Aloksan adalah turunan asam urat, dapat merusak sel pankreas secara selektif melalui mekanisme stres oksidatif. Aloksan menyebabkan penurunan glikogen hepatik dalam 2472 jam dan efek sitotoksisitasnya terutama disebabkan oleh karena konversi anion radikal yang menyebabkan kerusakan pankreas yang akhirnya menurunan kadar insulin (Lee et al., 2010).

Saat ini penggunaan aloksan untuk induksi DM lebih jarang dibanding streptozotosin karena tingkat keberhasilan aloksan kurang memuaskan dan adanya efek nefrotoksik dan hepatotoksik pada hewan coba. STZ diyakini lebih baik sebagai agen diabetogenik dibanding aloksan karena lebih efektif dan lebih reproducible. STZ juga stabil dalam larutan sebelum dan sesudah penyuntikan pada hewan coba. Selain itu, model hewan STZ lebih mirip dengan beberapa komplikasi akut dan kronis yang sering dijumpai pada penyandang DM. Model ini menunjukkan kesamaan pada beberapa abnormalitas struktural, fungsional dan biokimia penyakit DM sehingga lebih cocok sebagai model untuk memeriksa mekanisme DM (Eleazu et al., 2013; Lee et al., 2010).

Streptozotosin diinjeksi intraperioneal dengan dosis 35$65 \mathrm{mg} / \mathrm{kg}$ BB pada tikus dan 100-200 mg/kg BB pada mencit. Sedangkan dosis aloksan yang digunakan adalah 40-200 mg/kg.BB tikus atau mencit (Islam\&Loots, 2009). Terdapat beberapa tingkatan dosis streptozotosin

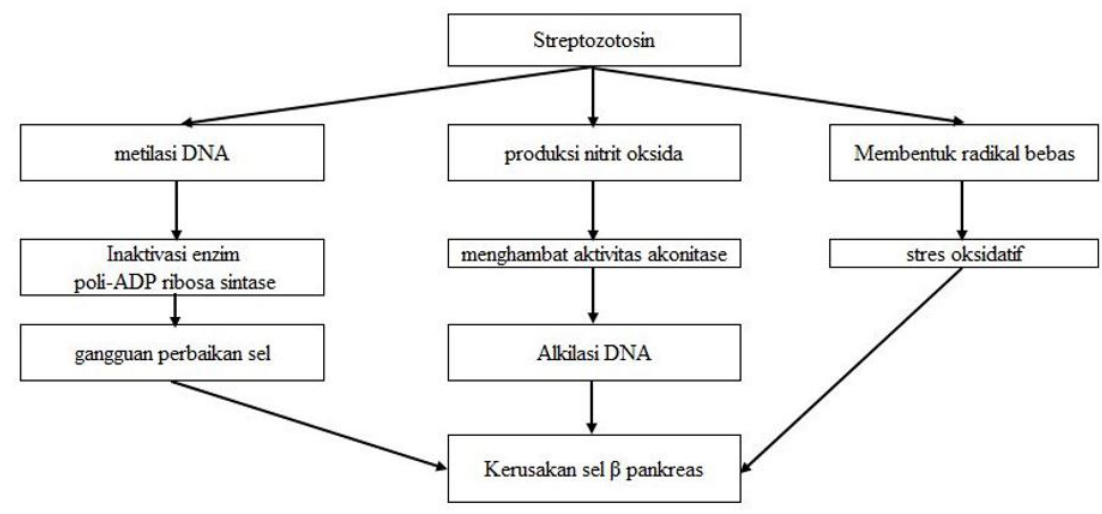

Gambar 1. Mekanisme kematian sel oleh STZ (Eleazu et al., 2013) 
yang digunakan seperti injeksi tunggal streptozotosin dosis tinggi ( $>65 \mathrm{mg} / \mathrm{kg} . \mathrm{BB})$, injeksi berulang dosis rendah $(<35 \mathrm{mg} / \mathrm{kg}$. BB) atau kombinasi streptozotosin dengan diet tinggi lemak. Injeksi streptozotosin dosis tinggi ( $>60 \mathrm{mg} / \mathrm{kg} . \mathrm{BB})$ menyebabkan kerusakan sel pankreas secara masif sehingga lebih mengarah kepada model hewan DM tipe 1 dan streptozotosin dosis menengah (antara 40-55 mg/kg.BB) menyebabkan gangguan sekresi insulin parsial seperti DM tipe 2 dan dosis tunggal streptozotosin $<35 \mathrm{mg} / \mathrm{kg}$.BB pada tikus diet normal tidak menunjukkan gambaran hiperglikemia (Srinivasan et al., 2005).

Karakteristik model hewan dengan metode ini adalah peningkatan kadar glukosa darah puasa atau sewaktu, penurunan kadar insulin dan hiperglikemia. Resistensi insulin tidak terjadi pada model ini. Karena keterbatasan ini, model ini dianggap model yang tidak cocok untuk DM tipe 2 tetapi masih bisa digunakan untuk skrining obat-obat antihiperglikemia atau insulinotropik (Dorothy, 2012).

Model induksi STZ atau aloksan juga dilakukan pada neonatus tikus. Model ini dikembangkan sejak pertengahan tahun 1970-an. STZ 25-90 mg/kg.BB diinjeksikan intraperitoneal pada tikus neonatus yang berusia 2 hari. Gambaran klinis DM mulai tampak pada minggu keempat dimana KGD sewaktu tikus sedikit meningkat. Pada saat tikus berusia 8-12 minggu KGD semakin meningkat dan gambaran klinis DM tipe 2 semakin jelas (Portha et al., 1974; Portha et al., 1979). Perbedaan gambaran klinis DM terjadi bila strain tikus yang digunakan berbeda. Optimasi dosis STZ sangat dibutuhkan (Shinde \& Goyal, 2003). Dosis aloksan yang digunakan adalah $200 \mathrm{mg} / \mathrm{kg}$.BB (i.p) pada tikus Spraque-Dawley jantan yang berusia 2, 4 atau 6 hari. Dalam hal mempertahankan keadaan diabetik yang lebih stabil, pemberian aloksan pada neonatus lebih efektif dibanding pemberian streptozotosin (Kodama et al., 1993).

Karakteristik model hewan ini adalah hiperglikemia ringan-sedang, peningkatan $\mathrm{HbA1C}$, glukosuria, peningkatan asupan makanan (polifagia). Sebuah penelitian menunjukkan bahwa model ini dapat mempertahankan keadaan diabetik dalam periode waktu yang lama (52 minggu) sehingga model ini dapat mempelajari patogenesis beberapa komplikasi DM (Iwase, 1991). Kekurangan metode ini adalah, memerlukan waktu yang lama, sekurangnya 12 minggu, untuk menginduksi DM sehingga model ini tidak cocok untuk skrining rutin obat antidiabetes (Dorothy, 2012).

\section{Model nikotinamid-streptozotosin (STZ-NA)}

Nikotinamid (NA) adalah inhibitor poli ADP ribosa polimerase (PARP) sehingga dapat menghambat metilasi DNA. Pemberian nikotinamid sebelum induksi dengan STZ dapat melindungi sel pankreas dari efek toksik STZ sehingga dapat mencegah perkembangan keadaan diabetes (Stauffacher et al., 1970). Model ini awalnya dikembangkan oleh Masiello dkk. Kemudian Nakamura dkk menggunakan model ini untuk mengembangkannya menjadi model DM tipe 2 non obesitas dan non genetik. Dasar pengembangan model ini adalah teori bahwa streptozotosin menyebabkan kerusakan DNA, kerusakan DNA akan memicu mekanisme perbaikan DNA yang membutuhkan nikotinamid adenin dinukleotida (NAD) dalam jumlah besar. Pemberian nikotinamid akan memproteksi sel pankreas sehingga tidak terjadi kerusakan masif. Derajat perubahan patologis pada hewan coba yang diinduksi dengan STZ-NA dan nikotinamid berbeda-beda tergantung kondisi penelitian. Kerusakan sel $\beta$ pankreas pada model hewan ini hanya sebagian, sedangkan pada model hewan yang diinduksi dengan streptozotosin saja menunjukkan nekrosis sel $\beta$ (Szkudelski, 2012).

Masiello dkk melakukan dengan menginjeksi tikus Wistar jantan berusia 3 bulan dengan nikotinamid 230 $\mathrm{mg} / \mathrm{kg}$.BB 15 menit sebelum injeksi streptozotosin (65 $\mathrm{mg} / \mathrm{kg}$.BB). Model ini menunjukkan gejala peningkatan KGD sewaktu dan gangguan toleransi glukosa (Masiello, 2006). Nakamura dkk (Nakamura et al., 2006) menggunakan mencit C57BL/6 jantan, berusia 5-6 minggu, diberikan streptozotosin dosis $100 \mathrm{mg} / \mathrm{kg}$. BB dua kali dan diberikan nikotinamid (230 mg/kg.BB) 15 menit sebelum injeksi streptozotosin. Szkudelski dkk melakukan penelitian yang komprehensif mengenai gangguan metabolik dan sekresi insulin pada tikus yang diinduksi dengan streptozotosin-nikotinamid, mereka membuktikan bahwa induksi streptozotosin-NA hanya sedikit mempengaruhi insulin, glukagon parameter metabolik, kadar sitokin proinflamasi di darah juga tidak berbeda dibanding kelompok kontrol. Selain itu, pada uji in vitro didapatkan bahwa model hewan ini, ketika sel distimulasi dengan glukosa fisiologis dan suprafisiologis, sekresi insulin pada sel islet menurun sekitar 20\% dibanding kelompok normal. Penurunan sekresi ini lebih rendah dibanding pada sel yang diinduksi hanya dengan streptozotosin (Masiello et al., 1998; Szkudelski et al., 2013). Model ini telah diujikan dengan obat anti diabetes sehingga dapat digunakan untuk skrining obat anti diabetes baru. 


\section{Model diet tinggi lemak}

Model ini dikembangkan pada akhir tahun 1980-an (Surwit et al., 1988). Model ini didasarkan pada fakta bahwa obesitas merupakan salah satu faktor risiko berkembangnya DM tipe 2 . Rodensia dapat diinduksi menjadi obesitas dengan meningkatkan asupan lemak (40-60\% dari total kalori). Kebutuhan kalori harian tikus adalah $10-15 \mathrm{kcal} /$ hari dan pakan standarnya telah tersedia dengan komposisi $65-70 \%$ karbohidrat, $20-25 \%$ protein dan $5-12 \%$ lemak dan total kalorinya adalah $2900 \mathrm{kcal} / \mathrm{kg}$. Peningkatan proporsi lemak (< $85 \%$ total kalori), karbohidrat, garam dan kolesterol dapat menginduksi model hewan untuk penelitian obesitas, resistensi insulin, hipertensi, aterosklerosis dan dislipidemia (Brito-Casillas et al., 2016).

Karakteristik model hewan diet tinggi lemak adalah obesitas, toleransi glukosa terganggu dan resistensi insulin. Beberapa penelitian yang mengembangkan model ini pada mencit C57BL/6 menemukan tanda resitensi insulin tapi sel pankreas tidak rusak bahkan ditemukan proliferasi sel pankreas (Surwit et al., 1988; Winzell \& Ahrén, 2004). Tikus strain Spraque-Dawley lebih efektif untuk model hewan diet tinggi lemak dibanding strain tikus lainnya. Pada durasi diet yang lebih panjang dijumpai hiperinsulinemia dan hiperlipidemia (Dorothy, 2012).

Salah satu pertimbangan yang penting diperhitungkan adalah usia memulai diet tinggi lemak. Diet tinggi lemak sebaiknya dimulai pada usia tikus muda (6-8 minggu) karena usia ini adalah usia efektif tikus berkembang menjadi obesitas (Reuter, 2007). Derajat hiperglikemia sangat tergantung pada jumlah lemak, tipe lemak dan durasi diet. Meskipun manifestasi diabetik sudah muncul setelah 4 minggu pemberian diet tinggi lemak tetapi keadaan DM akan lebih stabil apabila durasi diet tinggi lemaknya diperpanjang (Dorothy, 2012; Winzell \& Ahrén, 2004). Kekurangan metode ini adalah memerlukan waktu yang relatif panjang ( $>10$ minggu) untuk menginduksi model ini (Reuter, 2007).

\section{Model diet lemak - streptozotosin}

Model hewan ini termasuk model hewan yang sangat berguna dan mudah untuk dilakukan. Pada mulanya, tikus diberikan diet tinggi lemak selama periode waktu tertentu dan ketika usia dewasa tikus diberikan streptozotosin. Model ini sangat mirip dengan untuk menggambarkan patogenesis DM pada manusia. Dasar pemikiran model ini adalah pemberian diet tinggi lemak akan menyebabkan resistensi insulin dan streptozotosin dosis rendah akan merusak sebagian sel $\beta$ pankreas sehingga akan menghasilkan keadaan hiperglikemia yang stabil. Model ini akan memberikan manifestasi klinis defisiensi insulin dan resistensi insulin (Chen \& Wang, 2005).
Reed dkk menginduksi tikus Spraque-Dawley dengan memberikan diet diet tinggi lemak (40\% kalori) selama 2 minggu lalu dilanjutkan dengn injeksi streptozotosin (50 $\mathrm{mg} / \mathrm{kg}$ BB). Model tersebut menunjukkan resistensi insulin, hiperglikemia, penurunan kadar insulin plasma dan sensitif terhadap terapi metformin dan triglitazon (Reed et al., 2000). Beberapa peneliti lain juga menunjukkan bahwa model ini cocok untuk menguji bahan atau obat untuk terapi DM. Zhang dkk memodifikasi jumlah diet (30\% kalori) dan dosis streptozotosin (15 mg/kg BB) sehingga gangguan toleransi glukosa baru terjadi setelah 2 bulan kemudian dan hiperglikemia, hiperinsulinemia dan hiperlipidemia baru terjadi 2 bulan berikutnya (Zhang et al., 2008). Srinivasan $\mathrm{dkk}$, memberikan diet $58 \%$ kalori selama 2 minggu sebelum menginjeksi streptozotosin dengan dosis yang berbeda (25-55 $\mathrm{mg} / \mathrm{kg}$ BB) dan tetap diberikan diet tinggi lemak ad libitum. Berdasarkan penelitian ini didapatkan bahwa streptozotosin $35 \mathrm{mg} / \mathrm{kg}$ BB menunjukkan hiperglikemia, hiperkolesterolemia, hipertrigliserida dan penurunan kadar insulin. Hal ini menunjukkan bahwa jumlah diet dan dosis streptozotosin dapat mempengaruhi manifestasi diabetik hewan coba (Dorothy, 2012).

Perlu digarisbawahi bahwa beberapa literatur menunjukkan variasi pada gambaran klinis model hewan ini. Penelitian oleh Wang dkk dengan model diet tinggi lemak, streptozotosin dosis rendah membuktikan bahwa durasi diet tinggi lemak, dosis streptozotosin dan usia tikus adalah faktor-faktor penting dalam membuat model ini. Secara umum, diet tinggi lemak yang digunakan mengandung 40-50\% kalori dalam bentuk lemak diberikan selama 4-8 minggu dan dosis streptozotosin yang digunakan adalah $20-50 \mathrm{mg} / \mathrm{kg}$.BB. Pada salah satu penelitian dengan menggunakan tikus Spraque-Dawley usia 12 minggu, diberikan diet tinggi lemak selama 8 minggu lalu diberikan streptozotosin $20 \mathrm{mg} / \mathrm{kg}$.BB menunjukkan tingkat keberhasilan yang sangat rendah dalam menginduksi DM. Kelompok yang diberikan streptozotosin dosis $40 \mathrm{mg} / \mathrm{kg}$.BB menunjukkan tingkat kematian yang sangat tinggi setelah pemberian streptozotosin 2-4 minggu. Pada kelompok yang diberikan dosis streptozotosin 30 $\mathrm{mg} / \mathrm{kg}$.BB menunjukkan tingkat keberhasilan 90\% dan tingkat kematian dibawah $5 \%$ dan tikus tidak memerlukan terapi insulin untuk mempertahankan berat badan (Yorek, 2016).

Model ini juga sensitif dengan dua obat antidiabetes yang digunakan untuk terapi DM tipe 2 sehingga model ini sangat cocok untuk skrining obat antihiperglikemik baru. Tingkat keberhasilan induksi diabetes dengan metode ini lebih tinggi dibanding model lainnya dan merupakan pendekatan terbaik untuk menginduksi DM tipe 2 . 


\section{Model diet fruktosa}

Berbagai studi menunjukkan keunikan metabolisme fruktosa menyebabkan fruktosa lebih hiperlipidemik dibanding glukosa. Berdasarkan hal ini, para peneliti mengembangkan model diet fruktosa. Terdapat beberapa cara untuk menginduksi dengan diet fruktosa. Tikus diberikan diet yang mengandung 35-72\% fruktosa atau diberikan 10-15\% larutan fruktosa di dalam air minum selama 2-12 minggu. Dai dkk membuktikan bahwa pemberian larutan fruktosa 5-10\% menimbulkan gejala polidipsia dan dalam 14 minggu tikus mengalami kelebihan berat badan. Selain itu diet fruktosa selama 1 minggu atau lebih menyebabkan kenaikan tekanan sistol 20-25 mmHg pada tikus (Dai et al., 1994). Kekurangan model ini adalah waktu induksi yang panjang.

\section{Model pankreatektomi sebagian}

Model ini dikembangkan pertama sekali oleh Paul dan Bancroft. Pada tahun 1983 Bonner-Weir dkk meneliti tentang efek pengurangan massa sel pankreas dengan pembuangan $85-90 \%$ pankreas (Trent et al., 1983). Gambaran hiperglikemia ringan-sedang diperoleh setelah 4 hari operasi dan bertahan sampai 6 minggu. Selama 6 minggu tersebut, tidak terdapat perbedaan signifikan kadar insulin dan berat badan dibandingkan dengan kelompok normal, tetapi setelah 7 minggu KGD puasa dan kadar insulin kembali normal dan hanya mengalami hiperglikemia post prandial atau setelah pembebanan glukosa. Modifikasi dilakukan oleh Kurup dan Bhonde dengan mengkombinasi pankreatektomi $50 \%$ ditambah pemberian nikotinamid $350 \mathrm{mg} / \mathrm{kg}$ BB dan streptozotosin $200 \mathrm{mg} / \mathrm{kg}$ BB pada mencit BALB/c. Walaupun keadaan diabetiknya lebih stabil tapi gambaran klinis yang lebih dominan terlihat adalah gejala DM tipe 1 (Kurup \& Bhonde, 2000). Keuntungan metode ini adalah tidak menyebabkan efek samping pada organ lainnya dan model ini mirip dengan keadaan defisiensi insulin. Kekurangan utama metode ini adalah regenerasi dari sisa pankreas, teknik operasi dan gangguan pencernaan pada tikus.

\section{Model Intra Uterine Growth Retardation (IUGR)}

IUGR adalah berat badan bayi rendah karena terbatasnya sumber nutrisi fetus selama masa masa kehamilan dan merupakan ganguan kehamilan yang sering terjadi. Barker dkk adalah peneliti yang pertama memprediksikan bahwa IUGR berkaitan dengan perkembangan penyakit pada usia tua seperti obesitas, hipertensi dan DM tipe 2. Defisiensi nutrisi pada fetus menyebabkan modifikasi ekspresi gen dan fungsi sel di pankreas, hati dan otot. IUGR menyebabkan penurunan yang signifikan pada massa sel $\beta$ pankreas neonatus yang tidak dapat diperbaiki pada usia tua sehingga menyebabkan gangguan toleransi glukosa sehingga mencetuskan DM tipe 2 (Barker et al., 1993).

Pada tahun 2001, Simmons dkk mengembangkan model IUGR dengan meligasi arteri uterina bilateral sehingga meniru keadaan pada manusia dimana asupan nutrisi fetus tidak terpenuhi sempurna. Ligasi dilakukan pada usia kehamilan 19 hari (Simmons et al., 2001). Ketika dilahirkan, tikus memiliki berat badan yang sangat kurang disertai penurunan insulin. Pada usia 26 minggu tikus IUGR terlihat obesitas disertai peningkatan lemak sentral dan peningkatan KGD. Keuntungan model ini adalah model ini menunjukkan resistensi insulin, hiperglikemia, hiperinsulinemia, obesitas dan penurunan massa sel $\beta$ pankreas. Kekurangannya adalah teknik ligasi arteri uterina harus dilakukan oleh tenaga profesional, waktu induksi panjang (3 bulan) dan belum terbukti efek obat anti diabetes konvensional pada model ini (Hales CN, 1991).

\section{KESIMPULAN}

Penelitian in vivo untuk membuktikan patogenesis dan penatalaksanaan DM memerlukan model hewan coba yang sesuai. Saat ini belum ada model hewan coba tunggal yang dapat menjelaskan secara keseluruhan patogenesis DM. Pemilihan model hewan coba harus disesuaikan dengan desain dan tujuan penelitian. Setiap model hewan coba memiliki kelebihan dan kekurangan. Optimasi dan penyesuaian terhadap teknik untuk melakukan induksi sangat perlu dilakukan untuk mengurangi variasi antar hewan sehingga memudahkan dalam mengambil kesimpulan pada penelitian DM.

\section{DAFTAR ACUAN}

Barker DJP., \& Al E (1993). Type 2 (noninsulindependent) diabetes mellitus, hypertension and hyperlipidemia (syndrome X): relation to reduced fetal growth. Diabetologia, 36, 62-67.

Brito-Casillas, Y., Melián, C., \& Wägner, A.M. (2016). Study of the pathogenesis and treatment of diabetes mellitus through animal models. Endocrinología $y$ Nutrición, 63(7), 345-353. https://doi.org/10.1016/j. endonu.2016.03.011

Chen, D., \& Wang, M.W. (2005). Development and application of rodent models for type 2 diabetes. Diabetes, Obesity and Metabolism, 7(4), 307-317. https://doi.org/10.1111/j.1463-1326.2004.00392.x

Cui, Z. J., Zhou, Y. D., Satoh, Y., \& Habara, Y. (2003). A physiological role for protoporphyrin IX photodynamic action in the rat Harderian gland?. Acta Physiology Scandinavian, 179, 149-154. 
Dai, S., Todd, M. E., Lee, S., \& McNeill, J. H. (1994). Fructose loading induces cardiovascular and metabolic changes in nondiabetic and diabetic rats. Canadian Journal of Physiology and Pharmacology, 72(7), 771781.

Dorothy, I. S. and W. R. (2012). Animal Models in Diabetes Research. Animal Models in Diabetes Research, 933, 219-228. https://doi.org/10.1007/978-162703-068-7

Eleazu, C. O., Eleazu, K. C., Chukwuma, S., \& Essien, U. N. (2013). Review of the mechanism of cell death resulting from streptozotocin challenge in experimental animals, its practical use and potential risk to humans. Journal of Diabetes and Metabolic Disorders, 12(1), 60. https://doi.org/10.1186/2251-6581-12-60

Elsner, M., Guldbakke, B., Tiedge, M., Munday, R., \& Lenzen, S. (2000). Relative importance of transport and alkylation for pancreatic beta-cell toxicity of streptozotocin. Diabetologia, 43(12), 1528-1533. https://doi.org/10.1007/s001250051564

Goldner, M. G., \& Gomori, g. (1943). Alloxan diabetes in the dog1. Endocrinology, 33(5), 297-308. https://doi. org/10.1210/endo-33-5-297

Hales CN. (1991). Fetal and infant growth and impaired glucose tolerance at age 64. The British Medical Journal, 303, 1019-1022.

Hirsjarvi, P., Junnila, M., \& Valiaho, T. (1990). Gentled and non-handled rats in a stressful open-field situation; differences in performance. Scandinavian Journal of Psychology, 31, 259-265.

Hunt, J. V, Smith, C. C., \& Wolff, S. P. (1990). Autoxidative glycosylation and possible involvement of peroxides and free radicals in LDL modification by glucose. Diabetes, 39(11), 1420-1424.

Islam, M. S., \& Loots, D. T. (2009). Experimental rodent models of type 2 diabetes: a review. Methods and Findings in Experimental and Clinical Pharmacology, 31(4), 249-261. https://doi.org/10.1358/mf.2009.31.4.1362513

Iwase, M. (1991). A new animal model of non-insulindependent diabetes mellitus with hypertension: neonatal streptozotocin treatment in spontaneously hypertensive rats. Fukuoka Igaku Zasshi = Hukuoka Acta Medica, 82(7), 415-427.

Kaplan, J. R., \& Wagner, J. D. (2006). Type 2 diabetesan introduction to the development and use of animal models. ILAR Journal / National Research Council,
Institute of Laboratory Animal Resources, 47(3), 181185. https://doi.org/10.1093/ILAR.47.3.181

Kemmochi, Y., Fukui, K., Maki, M., Kimura, S., Ishii, Y., Sasase, T., Ohta, T. (2013). Metabolic disorders and diabetic complications in spontaneously diabetic Torii Lepr fa rat: A new obese type 2 diabetic model. Journal of Diabetes Research, 2013, 1-9. https://doi. org/10.1155/2013/948257

Kodama, T., Iwase, M., Nunoi, K., Maki, Y., Yoshinari, M., \& Fujishima, M. (1993). A new diabetes model induced by neonatal alloxan treatment in rats. Diabetes Research and Clinical Practice, 20(3), 183-189.

Kurup, S., \& Bhonde, R. R. (2000). Combined Effect of Nicotinamide and Streptozotocin on Diabetic Status in Partially Pancreatectomized Adult BALBc Mice. Hormone and Metabolic Research, 32, 330-334.

Lee, J. H., Yang, S. H., Oh, J. M., \& Lee, M. G. (2010). Pharmacokinetics of drugs in rats with diabetes mellitus induced by alloxan or streptozocin: comparison with those in patients with type I diabetes mellitus. The Journal of Pharmacy and Pharmacology, 62(1), 1-23. https://doi.org/10.1211/jpp.62.01.0001

Lenzen, S. (2008). The mechanisms of alloxan- and streptozotocin-induced diabetes. Diabetologia, 51(2), 216-226. https://doi.org/10.1007/s00125-007-0886-7

Lindsey, J., \& Baker, H. (2006). Historical perspectives. In: Suckow, M.A., Weisbroth, S.H., Franklin, C.L. (Eds.) The Laboratory Rat (2nd ed.). Elsevier Boston.

Masiello, P. (2006). Animal models of type 2 diabetes with reduced pancreatic $\beta$-cell mass. International Journal of Biochemistry and Cell Biology, 38(5-6), 873-893. https://doi.org/10.1016/j.biocel.2005.09.007

Masiello, P., Broca, C., Gross, R., Roye, M., Manteghetti, M., Hillarire-Buys, D., Ribes, G. (1998). Development of a new model in adult rats administered streptozotocin and nicotinamide. Diabetes, 47(February), 224-229.

Matsuoka, T., Kajimoto, Y., Watada, H., Kaneto, H., Kishimoto, M., Umayahara, Y., Yamasaki, Y. (1997). Glycation-dependent, reactive oxygen species-mediated suppression of the insulin gene promoter activity in HIT cells. Journal of Clinical Investigation, 99(1), 144-150. https://doi.org/10.1172/JCI119126

Maurer, K. J., \& Quimby, F. W. (2015). chapter 34 Animal Models in Biomedical Research. Laboratory Animal Medicine: Third Edition (Third Edit). Elsevier Inc.https://doi.org/10.1016/B978-0-12-4095274.00034-1

E-ISSN 2477-0612 
Medical, H. (1991). Molecular Mapping of the Mouse ob Mutation, 1062, 1054-1062.

Nakamura, T., Terajima, T., Ogata, T., Ueno, K., Hashimoto, N., Ono, K., \& Yano, S. (2006). Establishment and pathophysiological characterization of type 2 diabetic mouse model produced by streptozotocin and nicotinamide. Biological \& Pharmaceutical Bulletin, 29(6), 1167-1174. https://doi.org/10.1248/bpb.29.1167

National Research Council. (2011). Guide for the Care and Use of Laboratory Animal (8th ed.). Washington, DC: The National Academic Press.

Otto, G. M., Franklin, C. L., \& Clifford, C. B. (2015). Chapter 4 - Biology and Diseases of Rats. Laboratory Animal Medicine: Third Edition. https://doi.org/10.1016/ B978-0-12-409527-4.00004-3.

Pérez, C., Canal, J. R., Domínguez, E., Campillo, J. E., Guillén, M., \& Torres, M. D. (1997). Individual housing influences certain biochemical parameters in the rat. Laboratory Animals, 31(4), 357-361. https://doi. org/10.1258/002367797780596158

Portha, B., Levacher, C., Picon, L., \& Rosselin, G. (1974). Diabetogenic effect of streptozotocin in the rat during the perinatal period. Diabetes, 23(11), 889-895.

Portha, B., Picon, L., \& Rosselin, G. (1979). Chemical diabetes in the adult rat as the spontaneous evolution of neonatal diabetes. Diabetologia, 17(6), 371-377.

Rakieten, N., Rakieten, M. L., \& Nadkarni, M. V. (1963). Studies on the diabetogenic action of streptozotocin (NSC-37917). Cancer Chemotherapy Reports, 29, 9198.

Reed, M. J., Meszaros, K., Entes, L. J., Claypool, M. D., Pinkett, J. G., Gadbois, T. M., \& Reaven, G. M. (2000). A new rat model of type 2 diabetes: The fatfed, streptozotocin-treated rat. Metabolism: Clinical and Experimental, 49(11), 1390-1394. https://doi. org/10.1053/meta.2000.17721

Rees, D. A., \& Alcolado, J. C. (2005). Animal models of diabetes mellitus. Diabetic Medicine: A Journal of the British Diabetic Association, 22(4), 359-370. https:// doi.org/10.1111/j.1464-5491.2005.01499.x

Reuter, T. Y. (2007). Diet-induced models for obesity and type 2 diabetes. Drug Discovery Today: Disease Models, 4(1), 3-8. https://doi.org/10.1016/j.ddmod.2007.09.004

Saibaba, P., Sales, G. D., Stodulski, G., \& Hau, J. (1996). Behaviour of rats in their home cages: daytime variations and effects of routine husbandry procedures analysed by time sampling techniques. Laboratory Animals, 30(1), 13-21. https://doi.org/10.1258/002367796780744875

Sasase, T., Ohta, T., Masuyama, T., Yokoi, N., Kakehashi, A., \& Shinohara, M. (2013). The Spontaneously Diabetic Torii Rat: An Animal Model of Nonobese Type 2 Diabetes with Severe Diabetic Complications. Journal of Diabetes Research, 2013, 1-12. https://doi. org/10.1155/2013/976209

Shalev, U., Feldon, J., \& Weiner, I. (1998). Genderand age-dependent differences in latent inhibition following pre-weaning non-handling: implications for a neurodevelopmental animal model of schizophrenia. International Journal of Developmental Neuroscience : The Official Journal of the International Society for Developmental Neuroscience, 16(3-4), 279-288.

Shinde, U. A., \& Goyal, R. K. (2003). Effect of chromium picolinate on histopathological alterations in STZ and neonatal STZ diabetic rats. Journal of Cellular and Molecular Medicine, 7(3), 322-329.

Simmons, R. A., Templeton, L. J., \& Gertz, S. J. (2001). Intrauterine Growth Retardation Leads to the Development of Type 2 Diabetes in the Rat. Diabetes, $50,2279-2286$.

Srinivasan, K., \& Ramarao, P. (2007). Animal models in type 2 diabetes research: an overview. The Indian Journal of Medical Research, 125(3), 451-472.

Srinivasan, K., Viswanad, B., Asrat, L., Kaul, C. L., \& Ramarao, P. (2005). Combination of high-fat dietfed and low-dose streptozotocin-treated rat: A model for type 2 diabetes and pharmacological screening. Pharmacological Research, 52(4), 313-320. https://doi. org/10.1016/j.phrs.2005.05.004

Stauffacher, W., Burr, I., Gutzeit, A., Beaven, D., Veleminsky, J., \& Renold, A. E. (1970). Streptozotocin diabetes: time course of irreversible B-cell damage; further observations on prevention by nicotinamide. Experimental Biology and Medicine, 133(1), 194-200. https://doi.org/10.3181/00379727-133-34439

Suckow, M. A., Stewart, K. L., Hickman, D. L., Johnson, J., Vemulapalli, T. H., Crisler, J. R., \& Shepherd, R. (2017). Chapter 7 - Commonly Used Animal Models. Principles of Animal Research. Elsevier Inc. https://doi. org/10.1016/B978-0-12-802151-4.00007-4

Surwit, R. S., Kuhn, C. M., Cochrane, C., McCubbin, J. A., \& Feinglos, M. N. (1988). Diet-induced type II diabetes in C57BL/6J mice. Diabetes, 37(9), 1163-1167. 
Szkudelski, T. (2012). Streptozotocin-nicotinamideinduced diabetes in the rat. Characteristics of the experimental model. Experimental Biology and Medicine, 237(5), 481-490. https://doi.org/10.1258/ ebm.2012.011372

Szkudelski, T., Zywert, A., \& Szkudelska, K. (2013). Metabolic disturbances and defects in insulin secretion in rats with streptozotocin-nicotinamide-induced diabetes. Physiological Research, 62(6), 663-670.

Trent, D. F., Weir, G. C., \& Division, E. (1983). Partial pancreatectomy in the rat and subsequent defect in glucose-induced insulin release. Journal of Clinical Investigation, 71, 1544-1553.

Valentovic, M. A., Alejandro, N., Betts Carpenter, A., Brown, P. I., \& Ramos, K. (2006). Streptozotocin (STZ) diabetes enhances benzo(alpha)pyrene induced renal injury in Sprague Dawley rats. Toxicology Letters, 164(3), 214-220. https://doi.org/10.1016/j.toxlet.2005.12.009
Vergani, L., Floreani, M., Russell, A., Ceccon, M., Napoli, E., Cabrelle, A., Dabbeni-Sala, F. (2004). Antioxidant defences and homeostasis of reactive oxygen species in different human mitochondrial DNAdepleted cell lines. European Journal of Biochemistry, 271(18), 3646-3656. https://doi.org/10.1111/j.14321033.2004.04298.x

Winzell, M. S., \& Ahrén, B. (2004). The high-fat diet-fed mouse: a model for studying mechanisms and treatment of impaired glucose tolerance and type 2 diabetes. Diabetes, 53 Suppl 3, S215-9.

Yorek, M. A. (2016). Alternatives to the StreptozotocinDiabetic Rodent. International Review of Neurobiology (1st ed., Vol. 127). Elsevier Inc. https://doi.org/10.1016/ bs.irn.2016.03.002

Zhang, M., Lv, X.-Y., Li, J., Xu, Z.-G., \& Chen, L. (2008). The Characterization of High-Fat Diet and Multiple Low-Dose Streptozotocin Induced Type 2 Diabetes Rat Model. Experimental Diabetes Research, 2008, 1-9. https://doi.org/10.1155/2008/704045 